\title{
The ramifications of missionary proselytisation on Tiv culture: Lessons for contemporary critical biblical contextualisation
}

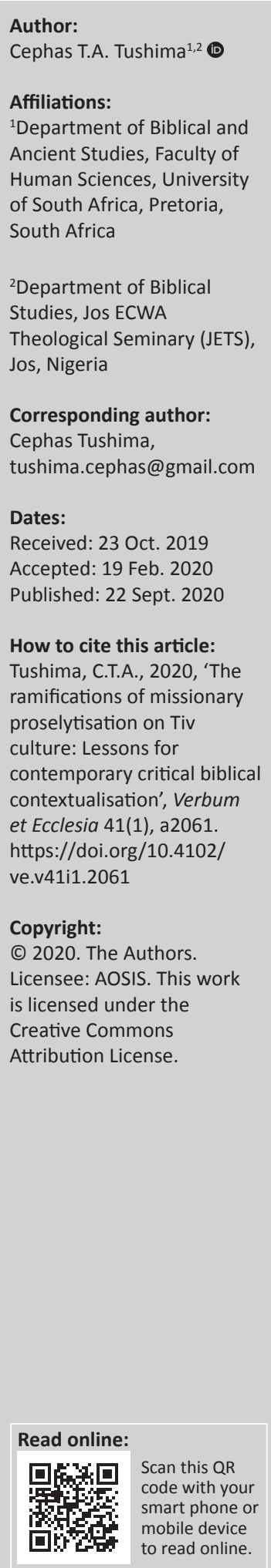

Christianity, from its inception, has always demonstrated a conscious effort to communicate the gospel in ways that engender transformation. Yet the undying presence of African indigenous religious practices amongst evangelised African communities continues to be a worrisome enigma. The goal of this article is to examine the contextualisation practices, successes and failures of early western missionaries, using literary critical analysis of contemporary literature and cultural phenomenological analysis, and to propose approaches to a biblical inculturation of Christianity in contemporary indigenous societies. We focus on the over 100 years of Christianity in northern Nigeria, with particular emphasis on the Tiv of central Nigeria. The author's research has shown that the relatively long presence of Christian mission work in Nigeria (especially amongst the Tiv) has not significantly altered the world view of the professed adherents of Christian faith, as it remains largely traditional rather than biblical. Consequently, we proposed the adoption of ethno-hermeneutic and community theologising to make for critical contextualisation of Christianity amongst indigenous people. The proposed critical contextualisation, is essential for rooting Christianity in native populations without uprooting them from their cultures, and for ensuring neither the gospel truth claims nor the Christian world view is surrendered to native cultures in the process of indigenising the gospel.

Intradisciplinary and/or interdisciplinary implications: This article highlights the importance of a holistic interdisciplinary approach to evangelisation, requiring the interplay of anthropology, missiology, hermeneutics, and dogmatic and exegetical theology.

Keywords: contextualisation; inculturation; indigenisation; Tiv; Dutch Reformed Church Mission; Roman Catholic Mission; Goemai; ethno-hermeneutics.

\section{Introduction}

The concern for communicating the gospel in terms relevant to recipient cultures is not a modern one, dating back to the apostolic times (see Ac 17). In extra-biblical literature, evidence of this is found in writings dating back to the apostolic and post-apostolic church fathers (see Chesnavage 2016:71-84; Stanley 2007:22). That the missionary endeavours of post-enlightenment modern missions had a huge impact on African (particularly Nigerian) cultures needs no proving. Yet evidence abounds that traditional religion is alive and doing well, with many adherents of scriptural religions continuing to patronise African indigenous religions (AIRs). On this, Adamo (2011:2) observes: 'AIR has become an essential element of indigenous knowledge systems; several steps have been taken by health workers and in Parliament to give recognition to African indigenous healers' (see also Mills 1995:153-175). Bascom and Herskovits (1975) capture the essence of this very well:

Despite the intensity of Christian missionary effort and the thousand years of Muslim proselytising which have marked the various parts of Africa, African religions continue to manifest vitality everywhere. This is to be seen in worship of African deities, the homage to ancestors, and the recourse to divination, magic, and other rituals. (p. 3)

All this points to gaps in the revealed religions (Christianity and Islam) passed on and as being practised by African peoples. It is in recognition of these gaps in contemporary Christianity that there is a growing inquiry into inculturation as a possible remedy for the evangelisation and traditioning practices of missionary Christianity and its successors in Africa. The thesis of this article is that the twofold goal of Christian missionaries, evangelising the Tiv people of central Nigeria and proselytising them, succeeded in radically altering the people's culture at the etic 
level without altering the mindset of the church at the emic level. We therefore set out here to examine the practices, successes and failures of early missionaries and use this as a springboard to propose approaches to a biblical inculturation of Christianity in contemporary indigenous societies.

\section{Reconnoitring contextualisation}

Attempts at domesticating the Christian religion into local African cultures have been called by different names at different times in the last 100 years. The term 'indigenisation' gained momentum amongst Protestant missions around the mid-20th century (Stanley 2007:22). The rise of the missiological concept of contextualisation is traceable to the 1971 World Council of Churches (WCC) 'Consultation on Dogmatic or Contextual Theology' (see Engle 1983:87; Hesselgrave 1979:4). The nudging from this consultation was picked up and developed further at the 1972-1973 conference of the Committee on World Missions and Evangelism (CWME) of the WCC, which was critical of 'theological imperialism' and which urged non-western churches to rephrase their understanding of the gospel and their walk with God 'in a theology, a liturgy, a praxis, a form of community, rooted in their own culture' (Engle 1983:87). The earliest users of the term were Shoki Coe, then director general of the WCC's Theological Education Fund (TEF), and Aharon Sapsezian, one of the four associate directors of TEF (Kinsler 1978: 24). By the time of the first Lausanne Congress on World Evangelisation in 1974, contextualisation was beginning to replace indigenisation. Expounding on the 1974 Lausanne conception of the term, Kato (1975) states:

This is a new term imported into theology to express a deeper concept than indigenisation ever does. We understand the term to mean making concepts or ideals relevant in a given situation. In reference to Christian practices, it is an effort to express the never changing Word of God in ever changing modes of relevance. Since the Gospel message is inspired but the mode of its expression is not, contextualisation of the modes of expression is not only right but necessary. (p. 1217)

Kato and his co-travellers at the 1974 Lausanne conference merely restated what classical indigenisation was about without grasping the new dynamic the term 'contextualisation' introduced into mission work. In the fullness of its reference, however, the term encompasses the understanding, conceptualisation and communication of the gospel in terms and forms that are cognisant of and in dialogue with the prevailing cultural, sociological, technological, socio-economic, human justice and spiritual conditions of the people being reached.

This full-orbed conception of the term is understood and implemented differently contingent on where one stands on the liberal-conservative continuum of the church. Engle (1983), after an interesting discussion of the term, concludes as follows:

In summary, contextualisation in missions is showing the whole Bible relevant to the total individual in all of life's relationships. The process must be deliberate. The sequence for accomplishment must be worked out while one plans his initial thrust into the target culture. (pp. 90-91)

Engle's (1983) analysis captures the conception of the originators of the term, who consciously sought to move a notch beyond the connotation of indigenisation, which stresses the anthropological aspects that the gospel needs to imbibe in acquiring indigeneity in its identification with the nations it reaches. Contextualisation incorporates the anthropological dimensions of indigenisation but seeks to add to the linguistic cultural dimensions inherent in indigenisation the component of socio-economic solidarity with the people in the redemptive work of the gospel.

In consonance with the above, Bosch (2011:358) notes that Ukpong (1987:163-168) identifies two major models of contextualisation (indigenisation and socio-economic models). The former consists of translation and inculturation, whilst the latter is evolutionary (e.g. political theology) and revolutionary (e.g. liberation theology). In Bosch's (2011) view, only inculturation and revolutionary models are the valid forms of contextualisation. The present author's discussion of inculturation provides the basis for his divergence from Bosch's position.

According to Iorliam (2015), the Catholic mission had used the term 'adaptation' in reference to its evangelisation approach. Explaining further, he states the following:

Adaptation suggests a situation whereby a foreign missionary announces the gospel message to suit the circumstances of the receiving culture. Faith adapts or accommodates itself in a limited fashion to the exigencies of cultural expression for the sake of the communication of the message. (p. 9)

As indigenisation amongst the Protestants, adaptation held sway amongst the Catholics from the early 1900s to the 1974 Roman Synod on evangelisation. Inculturation, the term corresponding to Protestant contextualisation, was first coined by Joseph Masson in 1962 and was introduced to the Synod of Bishops in 1977 by Pedro Arrupe, then superiorgeneral of the Jesuit Order (Bosch 2011:380). It was the use of the term by Pope John Paul II in his apostolic exhortation, Catechesi Tradendae, in 1979 that popularised it in missiological and scholarly parlance (Iorliam 2015:10).

Inculturation goes beyond adaptation's mere external aesthetic dressing of the gospel in cultural garb. Explaining further, Iorliam (2015) states that inculturation:

[S]ignifies an interior transformation of authentic cultural values through their integration into Christianity and the rooting of Christianity into various human cultures. It has the advantage of echoing the concept of incarnation, while at the same time emphasising the importance of culture and lifting up the relationship of faith and cultures as an ongoing process rather than a once-for-all encounter. (pp. 10-11)

The process of inculturation involves a metamorphosis of the values of a culture in its encounter with Christianity vis-à-vis the rooting of Christianity itself into that culture. 
The dynamic interplay between theology and culture draws on the tool of anthropology in an attempt to understand culture. By employing ethnography, one acquires a competent understanding of the culture of people as the means of finding appropriately meaningful cultural ways of expressing one's faith such that it connects with the people's heart. According to Iorliam (2015), theologically, the implication of inculturation is as follows:

[T] he Christian message, not just its external wrapping, needs to take flesh, become incarnate, in the patterns of thought, language, and symbols of a particular culture ... Like a tree that cannot bear fruit unless it takes root in the soil where it has been planted, so too faith needs to be planted and contextualised in the culture where it takes root so that it can bring forth fruit. To do this, faith needs to dialogue with the culture wherein it is contextualized. (p. 14)

This process calls upon the preacher to develop dual competencies in theology and the local culture (anthropology).

There are two assumptions in inculturation that raise concerns for evangelicals. Firstly, undergirding it is the anthropological assumption of the goodness of human person (Iorliam 2015:12). This flies in the face of the Reformation doctrine of the total depravity of human person which is informed by such scriptural passages as Job 4:17, Psalms 14:1-3, Proverbs 20:9, Ecclesiastes 7:20, Romans 3:23 and Galatians 3:22. Notwithstanding, this author's position as mentioned above is moderated by the evangelical teaching that the imago Dei remains in humanity, vitiated but not destroyed. This is augmented by the understanding that common grace ensures the presence of some non-redemptive good in human culture.

The second assumption, flowing from the first, is that the seed of the word is present in every culture (Iorliam 2015:14). At face value, this assumption sounds like the evangelical concept of redemptive analogies. However, there are significant differences. Redemptive analogies imply that embedded in every culture are echoes of divine truth that point humanity to God's revealed truth. Only the latter is redemptive; the former serve merely as springboards (in general revelation), linking culture to the truth. In inculturation, however, the presence of the seed of the word in culture implies that the presence of Christ already exists in the culture and missionaries are not his purveyors to native culture (Healey \& Sybertz 1996:25). This claim implies that the totality of the Christian doctrine, not just its externalities, needs to assume 'the patterns of thought, language, and symbols of a particular culture' (Iorliam 2015:14). This implies that Christianity would become accommodated to the world view of the host culture.

This discussion highlights the danger of syncretism lurking in pure inculturation. It has to be approached with the full understanding that Christianity comes with the view of redeeming the culture it encounters and imbuing it with a biblical world view. Nothing could be farther from the truth than to assume that Christ is already present in every culture (with the whole body of the Christian message) and is not brought there by any missionary. Tushima (2013) cautions in the following manner:

The core of the whole idea of proclamation is the concept of communication. Affirming oneself as a communicator presupposes a message (content) that one wishes to transmit. For the gospel proclaimer, the content (message) is the good news of the vicarious salvific work of Jesus of Nazareth in his life, death, and resurrection, within the redemptive historical context of the Christian Bible. Gospel proclaimers in the new world of the postmodern mindset, with its aversion to absolutes and incredulity to metanarratives, must remain committed to the absolutes of biblical truths and its metanarrative of redemptive history. It is only out of this commitment that true proclamation of the gospel will emerge. (p. 130)

In view of this huge divergence of perspectives, this author would maintain that the Protestants stick with the term 'contextualisation'. If we are to use inculturation, then it has to be redefined in a way that does not call on us to surrender 'the truth' of scripture for 'a good' in culture. Such a reconceived inculturation would acknowledge that every culture has customs or practices that are analogous to biblical truth and these should be pressed into service as vehicles (and vehicles only) for conveying the truth of scripture to the culture. Thus, for example, Richardson's (2005) peace child in Papua New Guinea points to the Prince of Peace - God's Peace Child par excellence, but that Papuan peace child is not Christ himself. That Christianity needs to be in continual dialogue with culture is not in doubt, but Christianity cannot assume the thinking patterns (world view) of local cultures in their totality. It can, as has been carried out previously, creatively take appropriate symbols and language forms from the culture and fill them with new meaning for effective communication of biblical truth, as the Apostle Paul did, for example, with the 'unknown god' in Acts 17.

\section{Early mission endeavours in Northern Nigeria}

The first four major mission agencies with significant work in northern Nigeria were the Church Missionary Society (CMS), Sudan Interior Mission (SIM), Sudan United Mission (SUM) and the Roman Catholic Mission (RCM). However, in this article, priority is accorded to the mission work of RCM and that of the Dutch Reformed Church Mission (DRCM, a sub-group of SUM) because these were the two missions that worked in Tiv land at the advent of Christianity. The Society of African Mission (SMA) of the French Province of the Catholic Church commenced work in northern Nigeria in 1907 in Shendam amongst the Goemai, at the direction of the colonial administration of Major U. F. Ruxton. The individual independent mission efforts of SIM started in 1893, with heavy casualties. The presence of SIM missionary began to have a foothold after 1910. Sudan United Mission's work started in 1911. The SUM was an umbrella body for different mission endeavours, not least the DRCM, which worked amongst 
Tiv people. The approaches of Catholic and Protestant missions had similarities as well as differences. The greatest difference between them was that while the Catholic missionaries worked in alliance with colonial administrators and received much of patronage from the latter, the Protestant missions tended to work at odds with colonial administration, thereby incurring the latter's wrath. For example, whilst the Catholic mission followed the colonial government's directives on civilising missions and staying out of Muslim enclaves, the Protestant missions focused on itinerant preaching and pressurised the government for full access to all areas for evangelisation (Barnes 1998:240-262).

Both the Catholics and Protestants were keen on spreading their influence and winning converts. Their divergent approaches resulted in the Catholic mission restricting itself to urban areas and serving southern immigrant populations, whilst the Protestants spread and covered many of the pagan areas of the north. From the 1930s, when the colonial government introduced the concept of Classes of Religious Instruction (CRI), the Catholics latched onto it immediately, and with the increasing desire of local population for western education (which the Protestants were not providing), the Catholics were able to play catch-up with the Protestants in their spread in rural areas. It was only the success of the Catholics that pushed the Protestants to embrace the inclusion of a robust educational curriculum in their evangelisation programmes beginning with CRIs in the 1940s (Barnes1998:252-253). From the 1950s onwards, the school (together with medical services) became a potent tool of mission work for both Catholic and Protestant missions.

\section{The outreach approaches of missionaries}

The RCM initially employed agriculture at the Goemai station and the care of southern Catholic immigrants in northern cities with the hope that they would reach uncivilised northerners. These all yielded little fruit. Although the colonial administrators and the missionaries had different goals - civilising the savages and evangelising the heathen, respectively - they found a confluence in the CRI programme. It both introduced and spread facets of western civilisation and opened doors for the evangelisation of the north.

The Catholics were savvy in their mission approach. They chose the path of least resistance to the government (initially, at least), as Monsignor Waller, the first prefect of Eastern Prefecture, reportedly used to say that survival was the first order of life (Barnes 1998:247). As a consequence of toeing government line, they latched onto the CRI policy early. This yielded heavy dividends of government patronage and the ability to capture the attention of natives and make proselytes, as they were enticed by the prospects of acquiring western education with the possibility of an attendant higher economic status. Similarly, they were less strict on moral issues such as alcoholism (see Barnes 1998:260; Crampton 1979:150; Walsh 1993:119). All these led to a rapid numerical growth in RCM from the 1930s.

As highlighted above, from the beginning, the Protestants had focused on itinerant preaching amongst the pagan societies, reporting growing numbers of converts. Baba (2009), writing on this, regarding SIM, notes:

Once the SIM established a base, their goal had been to spread out and establish mission stations over as wide a territory as possible. Then, from each station they trekked to village after village, sharing the gospel message. (p. 27)

Key to their work was to quickly prepare the new converts to become evangelists themselves. Outlining the evangelistic approach of SIM, which was typical of Protestant missions, Baba (2009) states:

The basic methods of the early SIM missionaries consisted of literacy, basic Bible teaching and apprenticeship. Classes were held several times a week. Sundays were strictly for worship services, baptismal classes, Bible studies and gospel team ministries. During baptismal classes, they taught Bible and doctrine. A pattern of evangelism was established and the new believers were taught, right from the beginning, to go out and share their knowledge of salvation through Jesus Christ with their relatives and neighbours and with those in nearby villages. (p. 28)

Barnes (1998) points out that Protestant missions tended to wage war against Islam and the traditions, customs and culture of the indigenous people of northern Nigeria. Barnes (1998: p. 260) concludes that such preaching did not motivate many people to become Christians. Iorliam (2015:71) illustrates the Protestant mission's war against culture with DRCM's fight against exchange marriage amongst the Tiv.

\section{The outcome of mission work}

Basic inferences could be drawn from this historical survey of missionary endeavours of both Catholic and Protestant missions. Overall, early missionary work focused on gaining converts ('proselytisation'). The inherent competition for converts between the Catholics and Protestants ineluctably tilted the scales in favour of the drive for numerical growth and occupation of large spans of territory. Little effort was expended in attempts to understand local cultures and their inherent world views. Consequently, there was little dialogue between the invading Christian faith and native cultures: the dark air of suspicion beclouded the ensuing acculturation of missionaries with locals. The former perceived native cultures as benighted and needing to be changed, whilst the latter looked upon the new ways as the 'spoiling' of the better-established ways that provided harmony, equilibrium and stability to their cosmos. The expression 'spoiling' is a translation of the Tiv term, vihi, which encapsulates their perception of degeneration and disintegration of their society in its encounter with westerners, especially regarding its beliefs, rituals, customs and practices, values, and institutions. 


\section{A sampling of negative Protestant mission outcomes}

As a consequence of the aforementioned misunderstanding of native cultures, there was an aggressive move (especially amongst Protestant missions) to change native cultural practices. A case in point is the 'exchange' (Yamishe) marriage system amongst the Tiv, which was fought to extinction in 1927 by the combined forces of colonialists and the DRCM, cheered on by Tiv youths (Torkula 2001:53). Similarly, in the 1920s, the DRCM, working in cahoots with the colonial administration, employed the youth as thugs to force the elders of Tiv land to abandon wizardry and surrender their wizardry artefacts. American anthropologist Rubingh (1962), about half a century ago, laid the charge that western missions and the colonial administration synergised and 'cooperated in demolishing the satanic structure' of Tiv culture because it was considered pagan. Rubingh (1962) keenly noted the following:

The changes that modernity has brought have forced the capitulation of the Tiv attitude toward change itself. With its demise the structure of Tiv thought has been irrevocably altered. The changes imposed from without by a colonial government, by business enterprise, by missions, by newspapers are now forcing the collapse of a venerable society. The old, to be sure, was never idyllic, yet the Westerner can scarcely assert that his product shows a great cultural superiority. (p. 5)

As the combination of brutal colonial administration, Christian mission and a tantalising western civilisation eroded the binding elements of Tiv culture, it inexorably collapsed gradually. The new converts to Christianity, however, lacked depth. Indeed, there emerged a large number of secularising local populations that no longer dreaded the taboos of ethnic fetish religion but were also not bound by the ethics and boundaries of new faiths. Rubingh (1962:5) insightfully identifies this vacuum, noting as follows: '[f]or those who cast off the fetish but do not turn to Christ (and they are legion), a spiritual and cultural vacuum opens wide'. The consequence of this was and continues to be devastating for both the general cohesion of Tiv society and its morality. One example from an abandoned rite of passage would suffice.

In traditional Tiv culture, morality was a highly prized virtue. The virginity of females in particular was not taken lightly. Thus, once a female child was weaned, she would be initiated into the cult of single spirit (Akombo à Igbanjôv), and its symbol (typically the shell of a small snail called Ikyôor would be tied around the neck of the girl. When the girl reached marriageable age and a suitor came for dowry payment, one of the requirements was to bring a young shegoat that had not yet given birth (Ivoàkyôor). Then there would be a cleansing rite of passage (Akôôr à saghen, 'the removal of the singleness bond'), during which the symbol of the single spirit would be removed from her neck and she would be handed over to her husband. It was believed that as long as she carried the symbol, she would be sterile and unable to bear children if she had pre-marital sex, and the male offender would become impotent. This way, purity was maintained.

The cleansing rite for Akôôr à saghen amongst the majority of Tiv people had a parallel variant known as Ier (ritual bathing) within two Tiv clans (the Ihyarev and Masev lineages). Both of these rituals converged at a point, although the latter was more elaborate, taking several days. Writing on this, Awuawuer (2017) states:

Here the Ier priest using some leaves, he dips in water from a hole dug in the ground. This by aesthetics is symbolic of a river that is meant to wash down the iniquities that might have befallen the woman to be washed. (pp. 325-336)

For both rites, the priest performing the ceremony, more often than not, an elderly woman, would bathe the initiate. As she bathes her, she would recite the words given in Table 1.

This cleansing rite was believed to have a twofold efficacy in the life of the initiate: firstly, it freed the young lady from fetish and mysterious forces (Akombo) that had been previously placed on her. Secondly, particularly for the Ier rite (which was for those who had already engaged in officially sanctioned pre-marital sex), it served to secure her progeny by ensuring her cleansing, a form of atonement (Torkula 2001:44). Western missionaries discountenanced both rites and worked to see them discontinued. Such crusading against African traditions was unaccompanied by the understanding of the underlying philosophy and morality as well as the functions they served in preserving the community. Without that knowledge, there was no deliberate effort to fill the vacuum created by the elimination of all fetish practices. In fact, western missions by nature since Constantine were not meant to do that. On this, Bosch (2011:380) states that Christian mission, 'as a matter of course, presupposed the disintegration of the cultures into which it penetrated. Where such disintegration did not take place, mission had only limited success'. By the time all forms of restraint were removed, the gates against all forms of perfidy in society were flung wide open, venting profligate carte blanche.

The cultural practices of people groups have overarching goals towards which they strive in accordance with their values. When alien values are superimposed on local

TABLE 1: The Incantation for the ritual bath of initiates during Tiv rites of passage of females from childhood to womanhood.

\begin{tabular}{|c|c|}
\hline Ritual incantation & Author's translation \\
\hline Ibo sen, Ishôkôndo & Guilt descent, right-standing ascend \\
\hline Ibo sen, Ishôkôndo & Guilt descent, right-standing ascend \\
\hline lyange wan nomso & The sun for the male child \\
\hline Uwer wan kwase & The moon for the female child \\
\hline Mnenge a nenge ga & I am not a copy cat \\
\hline Ôôn we nyiane [nyian ne] & I am cleansing you today \\
\hline Akombo a Tiv ci ca cii. & [By] all ritual cosmic powers of Tiv \\
\hline
\end{tabular}


populations without attention being paid to the subversion of their culture that gives them their sense of identity, security and solidarity, they are rendered rootless and society disintegrates. Rubingh (1962) bemoaned the disintegration of the hitherto close-knit Tiv society, held together by the tripartite pillars of Aôndo (the Tiv name for the supreme deity), Tsav (naturally endowed or mystically acquired supernatural powers with which to manipulate cosmic forces towards one's desires) and Tar (a loaded word that on the surface seemingly refers to a spatial territory, but is better thought of in terms of a realm, inclusive of a land, its people, the spirits and the inherit cosmic powers therein; hence, the avid attachment of the Tiv to their land), as traditional ways were being heedlessly replaced by an imported western Weltanschauung. Rubingh (1962) insightfully writes:

Today from thousands of compounds the young march off to school to learn the science that defies the fetishes of the old society and the religion that displaces the fear of magical malevolence. For those who cast off the fetish but do not turn to Christ (and they are legion), a spiritual and cultural vacuum opens wide. If tsav is but a fiction and there is no such potency to be reverenced, there is little further rationale for respect to the elders, and that respect has indeed declined. If the Tar is not spoiled after all by violation of a taboo, then whatever barriers to immorality exist dissolve. (p. 5)

Rubingh (1962) well understood the wreckage that this forced change was bringing. So regarding the case of virgins cited above, once the taboo was unmasked, the genie was let out of the box, and restive youth were liberated to explore to the fullest features and thrills of their sexuality, flowing with the surging tides brought by the hormonal changes of puberty and adolescent years.

The author concludes this section with a caveat: this article is not an assessment of the general impact of mission endeavours of DRCM (or even western Christian missions in general), for they did much good, especially in the fields of education, medical and healthcare services, and agriculture. This evaluation is limited to their manner of approach in the engagement of the gospel and culture. Even regarding this, one must pause to acknowledge the monumental work they accomplished in developing orthography for our local languages and their painstaking work of translating the Bible into our native languages (in the case of DRCM, the Tiv language). This has become an undying repository of our native languages, many of which are endangered at the moment.

\section{A sampling of negative Catholic mission's outcomes}

Whilst the Protestant missions were against the colonial government, local religious practices and the traditions of Africa, the Catholic missions in the north, in their first two decades, avidly allied with the colonial administration, becoming almost like its appendage. The poorly funded and staffed French Province SMA came on stream in 1907 and was recognised as the Apostolic Prefecture of Eastern Nigeria, even though it was largely confined in northern Nigeria, and when their work was taken over by the Irish Catholic mission in 1929, it was appropriately renamed as the Prefecture of Northern Nigeria. The first 20 years of the mission in northern Nigeria saw very little progress, as it limited itself to the dictates of colonial administration with its attendant benefits. Barnes (1998) aptly captures this as he observes:

The Catholic mission profited by the battle between colonial administrators and Protestant missionaries, becoming to administrators if not a model mission, at least one that they could point to as realizing their ideas of how a mission could best serve the region. These ideas were remarkably medieval. In its first incarnation, the Catholic mission, like some twelfth-century frontier abbey, served as an agricultural extension service, a dispensary, and a hostel for travellers going to and from Nigeria's northern and southern cities. (pp. 242-243)

In following the colonial administration's suggestion of engaging in civilising mission amongst the Goemai in Shendam, the Catholic missionaries in turn received patronage from colonialists, who supplied them with farm inputs and purchased fresh produce from them. Indeed, the willingness of French Catholic missionaries to serve as appendages to colonialists is also attested in Sudan (Barnes 1998:247). At the outbreak of smallpox in 1914, the mission again received vaccination supplies from the government. Likewise, during the Montol rebellion against colonial taxation, the colonialists used Catholic mission station at Shendam as their staging centre. This further alienated the mission from the people (Barnes 1998:243-244). Of the boys recovered from slave merchants, whom the colonial administration had sent to the mission, only a few had accepted baptism. In its first 10 years, 25 of the 34 baptised youth were at the verge of dying from disease. Similar to Protestant missionaries, the first leader of this mission, Msgr. Waller, opposed evangelisation through qualitative education on the belief that 'all that education produced was Africans full of pride and eager for material gain' (Barnes 1998:245).

The management of the French's Eastern Nigeria Prefecture was poor and ineffective, leaving the mission with little progress and quite a number of problems. One good example was their policy shift in the late 1920s from a focus on government-directed civilising mission amongst traditionalists to spiritual nourishment of southern Catholics, who were migrating north to work with colonial administration or for new business opportunities. For the southern Nigerian transplants to northern cities, the mission built schools and churches, whereas no such building was built in rural areas where they had been working with the natives. Whilst they spoke disparagingly of the northern traditionalists as 'naked cannibals, some of whom could not even count to ten', they spoke glowingly of the southern Catholic transplants to the north, even using terms of endearment to describe them as 'our people', who are 'intelligent and enterprising' (Barnes 1998:247-249). This inadvertently sowed seeds of discord in the nascent church, with the southerners having air of superiority over their 
northern brethren, and a sense of resentment and suspicion developed in northern Christians towards southerners. These ills have persisted in our midst till this day.

The inability of the French to manage the mission effectively caused Rome to transfer it to the Irish Province in 1929, and it was from this time on that the Catholic mission began to experience dynamic changes that led to its phenomenal growth. This change of guards could not have occurred at a more auspicious time, as the colonial administration had just come up with the new civilising mission policy of CRI. The departure of Msgr. Waller made the establishment of schools possible; and even though the government prohibited the use of southern educated Catholics as teachers in schools in the non-Muslim areas of north, the missionaries immediately set about raising teacher-catechists amongst their converts. This gave further impetus to the growth of the work. Whilst the Protestants in their characteristic anti-government stance dragged their feet in implementing the policy, the new leadership of the Catholic mission latched onto it with alacrity, giving it leverage over Protestant missions even in areas where the latter had been present for over a decade. Ozigi and Ocho (1982), for example, insightfully note as follows:

The Dutch Reformed Church working in Tiv land lost many of its converts to the Roman Catholic Mission because the Roman Catholics preferred to have a curriculum which met the expressed demand of the people for a full literary education that would afford employment in government and commercial firms. (p. 35)

It was only the amazing success of the Catholics that forced Protestant missions to start introducing a full-orbed educational curriculum, beyond vernacular literacy, in their mission work.

In playing catch-up to Protestant missionaries, the adaptation evangelisation policy of the Catholic Church came in handy. Rather than fight the traditions of the people headlong, the church adopted a more nuanced approach. For example, there was no prohibition of drinking, and polygamists were not asked to divorce all their wives but one (as required by Protestant missions), neither were there inquisitions into the fetish practices of indigenous people. This approach made the people feel more welcome in Catholic missions than in Protestant mission churches, and within a short time, throngs of people were trooping into RCM churches. Whilst the Protestants sought to uproot their converts from their cultures and traditions, leaving them with little sense of rootedness, the Catholics mounted new belief systems upon the old ways, resulting in syncretism: both were problematic. The world view of the adherents of the two branches of Christianity amongst Tiv people (as in other parts of Nigeria) has remained at core very traditional, and hence lacks depth in the professed biblical faith. It is little wonder that with all of the scores of millions who flock to churches every Sunday, the impact of the teachings of church on public morality and ethics remains invisible.

\section{Whither contextualisation?}

As long as the church continues to exist and engage local cultures, whether by indigenous believers or by cross-cultural missionaries, so long shall the gospel continue to engage culture. How that engagement proceeds is critical to its outcome. Indeed, the church in Africa has come of age and needs to re-conceptualise the gospel contextually. In view of the foregoing, the author set out here to make proposals for how that engagement could proceed in ways that ensure that the gospel incarnates in the host culture without surrendering its truthful values. The steps proposed here would aid the gospel proclaimer to ensure that the gospel takes roots in the culture and ceases to be alien, and yet retains its truth claims that also critique the culture at junctures where it is unhelpful, unjust or oppressive. In this way the gospel would be a liberating agent within culture, not only with regard to spiritual strongholds but also in the social, economic and, where necessary, in the political arena.

Firstly, contextualisation must be understood clearly. In view of the above discussion, this author is persuaded by Engle's (1983:100) definition of contextualisation: '[s]howing the whole Bible relevant to the total individual in all his relationships of life'. With this understanding, the gospel outreach ceases to be a one-track mission of converting souls and readying them for heaven; rather, it encompasses the regeneration and spiritual nurture of individuals, the experience of a positive influence oozing from the converts' union with Christ on their families and communities, the planting of New Testament-patterned worshiping assemblies with the band of converts, and such worshiping communities then reaching out to the larger society, proclaiming the whole truth of the Bible and addressing the total person with respect to the issues and challenges he or she faces in all of his or her relationships within his or her community.

Secondly, the duality of contextuality must be maintained. By this it means that the gospel we proclaim must incarnate into its host culture, reasonably appropriating that culture's critical elements of cultural knowledge, customs, values and institutions that do not contradict the scriptures, whilst at the same time being allowed to work like leaven to redeem culture through critical engagement to help it rid itself of components that are enmeshed in human fallibility that end up negating human good (often being unjust and oppressive) and ineluctably subverting divine creative and redemptive purposes.

Thirdly, the major task of contextualisation then is hermeneutical in nature, and executed in service of understanding the path towards attainment of a new self-understanding. It calls for the epistemic duality of understanding of the word (special revelations) and the world (general revelation). This on its part is pursued in addressing these seven hermeneutical questions: what? from whom? to whom? where? when? why? and how?

The 'what' question is critical and most fundamental to gospel communication. It addresses the matter of what is to 
be communicated. Compromise here compromises the mission. The gospel communicator must therefore understand the truth of the scripture that he or she is commissioned to take to the ends of the earth. This entails understanding the biblical text as it would have been understood by its first hearers (within its contexts and in accordance with its literary genres), and as it has been understood by the church through time, bearing in mind the context of contemporary readers and their hearers.

The 'from whom' question relates to issues of hermeneutical self-consciousness. The gospel communicator necessarily needs to attain good self-understanding: where is he or she coming from - from what culture, with what underlying world view and what attendant baggage. He or she also needs to be conscious of his or her own location in his or her journey of faith, what presuppositions dominate his or her frame of thought, and as such intentionally thinking through how he or she could minimise the imposition of his or her world views on others.

The 'to whom' question is an invitation to understand the target audience: its culture, its demographic composition and the dominant issues of its existence. Gaining this knowledge is essential to answer the questions this population is asking, that is, scratching it where it itches. With respect to the demographic composition, we must be cognisant of the differences concomitant with income levels, educational attainments and age groupings, as each of these creates differential understanding or even sub-cultural groups. For example, the contemporary gospel communicator needs to have a good grasp of the sub-cultures of ICT-savvy younger generations (the millennials, Generation $\mathrm{Z}$ and those after them) and the social media sub-culture generally and its mindset in order to communicate with them effectively.

Addressing the 'where' question calls for the understanding of the spatial and social location of the community to be reached with the gospel. Even where people share a common ethnic culture, their spatial and social locations imply that they are dealing with different existential issues. The issues in an upscale low-density suburb are different from those of a high-density urban ghetto, and these are radically different from those of the people living in remote countryside hamlets.

The 'when' question draws attention to the historical moment in which the gospel is being presented. The abiding flux of life makes it impossible to continue to use the past knowledge of people at the present time. As this study has demonstrated, anthropological studies of Tiv people of the mid-20th century can not accurately represent the contemporary Tiv people. This is applicable to any other group of people as well.

Heeding the 'why' question focalises the essence of the gospel message. This is where all the elements of the full-orbed definition of contextualisation as adopted in this article would be given adequate attention in view of biblical teachings vis$\grave{a}$-vis the existential situation of the target population.
The 'how' question is the point where all of the above discussion comes to a head, where all knowledge is harnessed to fashion appropriate strategies, methods and approaches of conscientiously, meaningfully and relevantly presenting the gospel to the target population for a thoroughgoing life transformation.

Fourthly, the final stage in this process involves the conscious development of an ethno-hermeneutic, a hermeneutical methodology for facilitating multidimensional dialogues that ought to continue dynamically between the gospel communicator, the biblical text, the church community (through time and contemporary) and the host culture. This is a call for community theologising, and it is not something that would be expected to occur within a few years of gospel presence within a pristine community. Rather, it presupposes a certain level of Christian discipleship (the very point where many mission churches in Africa are now located). At this stage, then, the emergent local Christian community is engaged by an expert gospel communicator (competent in Christian traditions as well as biblical and cultural exegesis) who would lead focused group-like discussions of biblical texts vis-à-vis cultural norms, customs and institutions. The gospel communicator serves only as a facilitator to provide expert knowledge of the biblical text and Christian world view, whilst the community members come to the table as experts in their own culture. In this engagement they are able to critique their own culture in the light of biblical teachings to see elements of it that need to be reinforced or changed and the best ways of reinforcing or changing them that do no violence to their culture overall. We may call this approach dynamic dialogical community hermeneutics.

\section{Conclusion}

This study focused on the impact of the methods of early Christian missionary evangelisation and proselytisation on the native cultures of northern Nigeria, with a particular focus on Tiv people. It demonstrated that the gross lack of cultural competence amongst the early western missionaries made them inflict monumental damages on the culture and psyche of Tiv people, albeit inadvertently. This has been used in assessing appropriate missional methodological approach for engaging the gospel and culture.

The key issue in the study is that the gospel must be presented in forms that connect with its target audience at heart, without harming them physically, psychologically, socially, culturally or environmentally. Steps must also be taken to ensure that the gospel is nativised in the culture it reaches without its own soul being lost, and at the same time, selectivity in its mission (exclusively focusing on its heavenly dimensions without attending to this-worldly concerns of its target population) must be avoided; rather, the totality of metaphysical and existential needs of the individual and the culture it reaches must be addressed so that they may be redeemed and transformed. 


\section{Acknowledgements}

The author thanks the Nigerian Association for Biblical Studies for the opportunity to present this article at its Annual General Conference held at Babcock University, Ogun State, Nigeria on 03-05 July, 2019.

\section{Competing interests}

The author has declared that no competing interests exist.

\section{Author's contributions}

The author declares that he is the sole author of this research article.

\section{Ethical considerations}

This article followed all ethical standards for research without direct contact with human or animal subjects.

\section{Funding information}

This research received no specific grant from any funding agency in the public, commercial or not-for-profit sectors.

\section{Data availability statement}

Data sharing is not applicable to this article as no new data were created or analysed in this study.

\section{Disclaimer}

The views and opinions expressed in this article are those of the author and do not necessarily reflect the official policy or position of any affiliated agency of the author.

\section{References}

Adamo, D.T., 2011, 'Christianity and the African traditional religion(s): The postcolonia round of engagement', Verbum et Ecclesia 32(1), Art. \#285, 10 p. https://doi. org/10.4102/ve.v32i1.285
Awuawuer, T.J., 2017, 'The aesthetics and cultural relevance of the ler ritual festival among the Tiv of central Nigeria', Africology: The Journal of Pan African Studies 10(1), 325-336.

Baba, P., 2009, A vision received, a vision passed on: The history of EMS of ECWA 1948-1998, Africa Christian Textbooks (ACTS), Jos.

Barnes, A.E., 1998, 'Catholic evangelizing in one colonial mission: The institutional evolution of Jos prefecture, Nigeria, 1907-1954', The Catholic Historical Review 84(2), 240-262. https://doi.org/10.1353/cat.1998.0087

Bascom, W.R. \& Herskovits, M.J. (eds.), 1975, Continuity and change in African cultures, University of Chicago Press, Chicago, IL.

Bosch, D.J., 2011, Transforming mission: Paradigm shifts in theology of mission, 20th anniversary edn., Orbis Books, Maryknoll, NY.

Chesnavage, C.S., 2016, 'Principles from inculturation as a key to interreligious prayer: Being religiously revelatory and educative in a diverse world', PhD dissertation
submitted to the Faculty of the Graduate School of Religion and Religious submitted to the Faculty of the Graduate
Education, Fordham University, New York.

Crampton, E.P.T., 1979, Christianity in northern Nigeria, p. 150, Geoffrey Chapman, London.

Engle, R.W., 1983, 'Contextualization in missions: A biblical and theological appraisal', Grace Theological Journal 4(1), 85-107.

Healey, J. \& Sybertz, D., 1996, Toward an African narrative theology, Orbis, Maryknoll, NY.

Hesselgrave, D.J., 1979, 'Contextualization continuum', The Gospel in Context 2(3), $4-26$.

Iorliam, C.T., 2015, 'Educated young people as inculturation agents of worship in Tiv culture: A practical theological investigation of cultural symbols', Unpublished dissertation submitted to the Faculty of St. Thomas University, Miami Gardens, FL.

Kato, B.H., 1975, 'The Gospel, cultural context and religious syncretism', in J.D. Douglas (ed.), Let the earth hear his voice: International Congress on World Evangelization Lausanne, Switzerland, p. 1217, World Wide Publications, Minneapolis, MN.

Kinsler, F.R., 1978, Mission and Context: The Current Debate about Contextualization, viewed 24 June 20198, from https://missionexus.org/mission-and-context-thecurrent-debate-about-contextualization/.

Mills, W. 1995, 'Missionaries, Xhosa clergy and the suppression of African traditional custom', in H. Bredencamp \& R. Ross (eds.), Mission and Christianity in South African history, pp. 153-175, University of Witwatersrand Press, in South African

Ozigi, A. \& Ocho, L., 1982, Education in northern Nigeria, Allen \& Unwin, London.

Richardson, D., 2005, Peace child, Bethany House, Bloomington, MN.

Rubingh, E., 1962, 'The Fall of a world-view', The Reformed Journal 12(2), 3-5.

Stanley, B., 2007, 'Inculturation: Historical background, theological foundations and contemporary questions', Transformation 24(1), 22. https://doi.org/10.1177/ 026537880702400104

Torkula, A.A., 2001, 'A survey of marriage and burial institutions amongst the Tiv of central Nigeria', PhD dissertation submitted to St. Clements University, Turks and Caicos.

Tushima, C.T.A., 2013, 'Toward an ortho-Kerygma in the urban economy', Torch Trinity Journal 16(2), 118-138.

Ukpong, J., 1987, 'What is contextualization?', Neue Zeitschriftfür Missions wissenschaft 43, 161-168.

Walsh, J., 1993, The growth of the Catholic Church in the diocese of Jos 1907-1978: The contribution of the society of Africa missions to its development, Ambassado Publications, Iperu-Remo. 